\title{
Noncitrus Fruits as Novel Dietary Environmental Modifiers of Iron Stores in People With or Without HFE Gene Mutations
}

\author{
Elizabeth A. Milward, PhD; Surinder K. Baines, PhD; Matthew W. Knuiman, PhD; \\ Helen C. Bartholomew, GradDipComp; Mark L. Divitini, BAppSc; David G. Ravine, MD; \\ David G. BRuce, MD; and John K. OlynyK, MD
}

OBJECTIVE: To investigate whether citrus fruit, noncitrus fruit, and other dietary factors act as environmental modifiers of iron status in the absence or presence of hemochromatotic HFE gene mutations.

PARTICIPANTS AND METHODS: Iron studies, HFE genotypic analyses, and dietary data from a survey conducted from March 21 , 1994 , through December 15, 1995, were analyzed for a group of 2232 residents (1105 men, 1127 women) aged 20 to 79 years recruited from the community electoral roll of Busselton in Western Australia. Data were analyzed by linear regression analysis and analysis of covariance.

RESULTS: Higher levels of fresh fruit intake (excluding citrus fruits and citrus juices) had a significant protective effect $(P=.002)$ against high body iron status as gauged by ferritin levels in men, irrespective of HFE genotype. Consumption of 2 or more pieces of fruit per day on average reduced mean serum ferritin levels by $20 \%$ compared with average consumption of less than 1 piece of fruit per day. This effect was not observed in women. Consumption of citrus fruits and citrus juices had no significant effects in either sex. No protective effects were observed for tea consumption or any other dietary factors studied. Red meat and alcohol consumption correlated with high body iron stores $(P<.05)$, consistent with previous studies, but did not interact with fruit with regard to effects on serum ferritin $(P>.05)$.

CONCLUSION: Noncitrus fruits are environmental modifiers of iron status independent of HFE genotype. This could have important implications for the provision of evidence-based dietary advice to patients with other iron-storage disorders

Mayo Clin Proc. 2008;83(5):543-549

$\mathrm{BMI}=$ body mass index $\mathrm{HH}=$ hereditary hemochromatosis

$\mathrm{H}$ ereditary hemochromatosis $(\mathrm{HH})$ is a common autosomal recessive disorder characterized by inappropriate control of iron absorption, resulting in excess accumulation of iron in organs such as the liver, heart, and pancreas, which can eventually lead to organ dysfunction. ${ }^{1-4}$ Hereditary hemochromatosis affects approximately 1 in 200 people and has a carrier frequency on the order of 1 in 10 individuals of northern European descent. ${ }^{3,4}$ The gene most commonly implicated in $\mathrm{HH}$ is the $H F E$ gene on chromosome $6 .^{5}$ Most cases of $\mathrm{HH}$ are caused by a homozygous mutation in the $H F E$ gene that results in a $\mathrm{C} 282 \mathrm{Y}$ mutation of the HFE protein. A second HFE gene mutation, H63D, can also contribute to $\mathrm{HH}$, usually only if present in conjunction with the $\mathrm{C} 282 \mathrm{Y}$ mutation. ${ }^{1-4}$

A recent systematic review estimates $10 \%$ to $33 \%$ of C282Y homozygotes develop hemochromatosis-associ- ated morbidity (fibrosis or cirrhosis) or other clinically relevant symptoms. ${ }^{3}$ Liver damage increases the risk of potentially fatal consequences, such as hepatocellular carcinoma, but can be prevented or even, if not too advanced, reversed by reduction of iron load. ${ }^{6}$ Thus, it is of value to identify lifestyle factors that help reduce iron levels.

Few studies of dietary factors and iron status have considered the HFE genotype. Two European studies found heme iron consumption was associated with higher serum ferritin levels in compound heterozygous or C282Y-homozygous women. ${ }^{7,8}$ In contrast, 2 Australian studies ${ }^{9,10}$ found no significant interactions of red For editorial comment, see page 526 meat with $H F E$ genotype for either sex. Similar results were obtained in a study of $\mathrm{HH}$ in Welsh families by McCune et $\mathrm{al}^{11}$; intriguingly, these researchers observed that fresh fruit intake protected against iron overload in individuals genetically at risk. This finding, which is potentially important not only for those with $\mathrm{HH}$ but also for the many people at risk of iron overload from other causes, requires validation in other populations, particularly as it is inconsistent with other reports that fruit intake had no effect on iron measures in middle-aged women ${ }^{12}$ or that fruit increases dietary iron uptake. ${ }^{13,14}$

One possible source of discrepancy is that different fruits can affect gastrointestinal iron absorption differently depending on citric and ascorbic acid content. ${ }^{15}$ Orange juice has been associated with increased uptake of dietary nonheme iron, prompting suggestions that the citric acid and ascorbic acid in oranges and orange juice act individu-

From the School of Biomedical Sciences and Hunter Medical Research Institute (E.A.M.) and School of Health Sciences (S.K.B.), University of Newcastle, Callaghan, NSW, Australia; School of Population Health (M.W.K., H.C.B., M.L.D.), School of Medicine \& Pharmacology (D.G.R., D.G.B., J.K.O.), and Western Australian Institute for Medical Research (D.G.R., J.K.O.), University of Western Australia, Fremantle, WA, Australia.

Financial support: Supported by grants from the National Health and Medical Research Council of Australia (\#254594), the Health Promotion Foundation of Western Australia, and the Great Wines Estates of the Margaret River region.

Individual reprints of this article are not available. Address correspondence to John K. Olynyk, MD, School of Medicine and Pharmacology, University of Western Australia, Fremantle Hospital Campus, PO Box 480, Fremantle, WA 6959, Australia (john.olynyk@uwa.edu.au).

(C) 2008 Mayo Foundation for Medical Education and Research 
ally or synergistically to increase iron uptake, ${ }^{16}$ possibly in combination with other organic acids present in fruit, such as malic acid. ${ }^{14,16} \mathrm{McCune}$ et $\mathrm{al}^{11}$ did not investigate citrus fruits separately from other fruits.

To assess whether fruit might be an environmental modifier of iron status and to provide information on the effects of fruits and other dietary factors, we investigated associations between consumption of citrus and noncitrus fruits and other dietary components, HFE genotype, and serum ferritin in a group of 2232 Australian community residents.

\section{PARTICIPANTS AND METHODS}

Residents of the town of Busselton, Western Australia, have participated in repeated cross-sectional health surveys since 1966. The population is predominantly of AngloCeltic ancestry. From March 21, 1994, through December 15,1995 , all surviving participants of earlier cross-sectional surveys, who had been recruited from community electoral rolls, were invited to participate in a follow-up survey. Of 10,076 eligible participants, 7711 (76\%) were contacted; of these, 4831 (63\%) completed a questionnaire, attended the clinic, and provided a blood sample. ${ }^{17,18}$ After exclusions, complete data on HFE genotype and relevant dietary information, including alcohol consumption levels, were available for 2232 participants aged 20 to 79 years (1105 men, 1127 women).

Written informed consent was obtained from all participants. The mortality and hospital morbidity linkage was approved by the Confidentiality of Health Information Committee of Western Australia, and all protocols and analyses were approved by the Human Research Ethics Committee of the University of Western Australia.

The current analyses are restricted to people at least 20 years old when surveyed. Pregnant women were excluded from the analyses because pregnancy can substantially alter both iron status and dietary patterns temporarily. People with body mass index (BMI) under 16 (ie, possibly malnourished) were also excluded. Because alcohol consumption influences serum ferritin levels within the Busselton population, ${ }^{19}$ people who reported alcohol consumption but failed to report an amount (17 men, 23 women) were also excluded.

\section{Statistical Analyses}

Serum ferritin levels and C282Y and H63D mutations of the $H F E$ gene were determined as previously described from a fasting blood sample at the time of survey. ${ }^{17}$ Analysis of 9 randomized controlled trials by the US Centers for Disease Control and Prevention recently validated serum ferritin level as an appropriate indicator of population responses to factors influencing iron status. ${ }^{20}$ Inspection showed the distribution of ferritin values to be skewed, hence it was transformed logarithmically for analyses. However, to facilitate interpretation, ferritin levels are presented in tables as back-transformed mean values, on the original scales. Linear regression analyses of logarithmically transformed (ln) ferritin on diet and other variables were performed using the General Linear Model Procedure in the SAS statistical software, version 9 (SAS Institute, Cary, NC). Each diet variable was analyzed separately for an association with $\ln$ (ferritin) in men and women. The comparison of mean $\ln$ (ferritin) across the levels of the diet variable was assessed using an overall analysis of covariance $F$ test (with degrees of freedom being 1 less than the number of levels) after adjustment for age only and then again after further adjustment for the following potential confounders: BMI, history of ulcer, doctor-diagnosed diabetes, anemia defined using World Health Organization criteria of hemoglobin less than $13.0 \mathrm{~g} / \mathrm{dL}$ for men and less than $12.0 \mathrm{~g} / \mathrm{dL}$ for women (to convert to $\mathrm{g} / \mathrm{L}$, multiply by 10), blood donation, menopausal status, hysterectomy, and $H F E$ genotype.

Because there was very little difference between ageadjusted and multivariate-adjusted $P$ values, only multivariate-adjusted $P$ values and multivariate-adjusted means are presented. Raw (unadjusted) mean ferritin levels for each diet variable are presented for comparison. Groups were classified according to HFE genotype as follows: (1) carriers of homozygous $\mathrm{C} 282 \mathrm{Y}$ and compound heterozygous C282Y/H63D, (2) carriers of any C282Y or H63D allele, and (3) those with no C282Y or H63D alleles. Height was measured while participants were barefoot by stadiometer. Weight was measured with participants in light underclothes. The BMI, reported to be positively correlated with serum ferritin levels in $H F E$ wildtype patients, ${ }^{9}$ was derived as the weight in kilograms divided by the square of the height in meters.

We investigated the interaction between $H F E$ genotype and each dietary variable to see whether the variable's effect on ferritin was associated with various $H F E$ genotypes. We also investigated the possibility of interactions between alcohol or red meat and fruit consumption.

\section{RESULTS}

Characteristics of the group with respect to age, BMI, and confounders, as well as with respect to the HFE C282Y and H63D mutations, are summarized in Table 1. The frequencies of the HFE C282Y and H63D mutations in this group are similar to those reported previously for the Busselton population $^{17}$ and other populations of northern European descent. ${ }^{3,4}$ 
IRON MEASURES

Table 2 shows the age trends in serum ferritin levels. Overall, the average serum ferritin level increased with age for both sexes, consistent with past literature. ${ }^{21,22}$ All analyses were therefore performed on age-adjusted data. In addition, information available on a range of potential confounding variables was used for multivariate adjustments.

Table 3 shows the specific questions we asked about each diet variable and gives the unadjusted and multivariate-adjusted means for serum ferritin and $P$ values in relation to each of the diet variables for men and women. The findings after multivariate adjustment of data were similar to those obtained after age adjustment only (data not shown) and are summarized below.

\section{Consumption of Fruits and Vegetables}

Higher fresh fruit intake, excluding citrus fruits and citrus juices, was associated with significantly reduced serum ferritin levels in men for both age-adjusted and multivariate-adjusted values ( $P=.002$, Table 3$)$. Adjusted mean ferritin levels were reduced with consumption of 7 or more pieces of fruit per week, with the lowest mean and adjusted mean ferritin levels seen with consumption of 14 or more pieces of fruit per week (Table 3 ) (ie, 2 or more pieces of fruit daily on average). This level of consumption was associated with a reduction of approximately $20 \%$ below the mean value of approximately $180 \mu \mathrm{g} / \mathrm{L}$ (to convert to $\mathrm{pmol} / \mathrm{L}$, multiply by 2.247 ) of ferritin seen in the groups consuming 0 to 6 pieces of fruit per week (ie, $<1$ piece of fruit daily on average). No significant effects of any kind $(P>.1)$ were observed for fresh fruit consumption in women (Table 3). Consumption of citrus fruits and citrus juices (specifically orange and grapefruit) did not confer protective effects, with no significant effects on serum ferritin levels in either sex (Table 3). Consumption of vitamin $\mathrm{C}$ alone or as part of a multivitamin supplement did not affect serum ferritin levels in either sex $(P>.1$, data not shown).

In general, consumption of potatoes, other cooked vegetables, or salads had no substantial effects on serum ferritin levels in either sex whether adjusted for age only or for age and other variables. Significant but marginal decreases of $10 \%$ or less in serum ferritin levels after multivariate adjustment were observed among women but not men with lower consumption of cooked vegetables (Table 3).

A total of $15.3 \%$ of premenopausal women had iron deficiencies (ferritin $<15 \mu \mathrm{g} / \mathrm{L}$ ) with or without anemia. We examined whether protective effects might be restricted to postmenopausal women not protected from iron overload by iron loss through menstruation; however, noncitrus fruit had no significant effect on serum ferritin levels in postmenopausal women $(P=.99)$. The data do not
TABLE 1. Characteristics and HFE Genotype of the Study Group ${ }^{\mathrm{a}}$

\begin{tabular}{|c|c|c|}
\hline Characteristic & $\begin{array}{c}\text { Men } \\
(\mathrm{n}=1105)\end{array}$ & $\begin{array}{l}\text { Women } \\
(\mathrm{n}=1127)\end{array}$ \\
\hline Age $(y)$, mean \pm SD & $50.6 \pm 14.9$ & $51.6 \pm 14.8$ \\
\hline $\mathrm{BMI},{ }^{\mathrm{b}}$ mean $\pm \mathrm{SD}$ & $26.6 \pm 3.3$ & $25.7 \pm 4.6$ \\
\hline History of ulcer (duodenal, gastric, peptic) & $166(15.0)$ & $107(9.5)$ \\
\hline Physician-diagnosed diabetes & $51(4.6)$ & $59(5.2)$ \\
\hline Anemia by WHO criteria & $25(2.3)$ & $52(4.6)$ \\
\hline Donated blood at least once & $421(38.1)$ & $348(30.9)$ \\
\hline Postmenopause & NA & $598(53.1)$ \\
\hline Had hysterectomy & NA & $233(20.7)$ \\
\hline \multicolumn{3}{|l|}{$H F E$ genotype } \\
\hline \multicolumn{2}{|l|}{ Group 1 (C282Y/C282Y or } & $29(2.6)$ \\
\hline \multicolumn{3}{|l|}{ Group 2 (other $\mathrm{C} 282 \mathrm{Y}$ or } \\
\hline H63D genotypes) & $442(40.0)$ & $431(38.2)$ \\
\hline Group 3 (no C282Y or H63D alleles) & $636(57.5)$ & $667(59.2)$ \\
\hline \multicolumn{3}{|c|}{$\begin{array}{l}{ }^{\text {a }} \text { Continuous variables are expressed as mean } \pm \mathrm{SD} \text {; categorical variables } \\
\text { are expressed as number (percentage). BMI }=\text { body mass index; NA } \\
\text { not applicable; } \mathrm{WHO}=\text { World Health Organization. }\end{array}$} \\
\hline \multicolumn{3}{|c|}{$\begin{array}{l}{ }^{6} \text { Calculated as the weight in kilograms divided by height in meters } \\
\text { squared. }\end{array}$} \\
\hline
\end{tabular}

allow us to assess potential effects in postmenopausal C282Y-homozygous women.

\section{Consumption of Animal Products (Red Meat, Liver and Offal, Eggs)}

Consumption of red meat was high; approximately $75 \%$ of men and $65 \%$ of women consume red meat 4 times or more a week. As expected, for both men and women, higher consumption frequency was significantly associated with multivariate-adjusted mean serum ferritin levels. Significant associations were also observed when data were adjusted for age only. Consumption of liver or kidney was generally associated with higher mean serum ferritin levels in both sexes but failed to reach significance (set at $P<.05$ ) (Table 3 ).

Because red meat consumption was associated with higher mean serum ferritin levels, we examined whether the lower levels seen with high fruit consumption might have been due to people with greater fruit consumption consuming less red meat. The proportions of both men and women

TABLE 2. Serum Ferritin Levels, Stratified by Sex and Age

\begin{tabular}{lrcrrc}
\hline & \multicolumn{2}{c}{ Men } & & \multicolumn{2}{c}{ Women } \\
\cline { 2 - 3 } \cline { 5 - 6 } Age $(\mathrm{y})$ & No. & $\begin{array}{c}\text { Geometric mean } \\
(\mu \mathrm{g} / \mathrm{L})^{\mathrm{a}}\end{array}$ & & No. & $\begin{array}{c}\text { Geometric mean } \\
(\mu \mathrm{g} / \mathrm{L})^{\mathrm{a}}\end{array}$ \\
\hline $20-29$ & 89 & 129.6 & 93 & 41.3 \\
$30-39$ & 221 & 178.0 & & 191 & 45.6 \\
$40-49$ & 238 & 180.0 & & 238 & 38.8 \\
$50-59$ & 216 & 170.2 & & 234 & 80.3 \\
$60-69$ & 215 & 162.9 & & 221 & 90.2 \\
$70-79$ & 126 & 137.7 & & 150 & 83.7 \\
Total & 1105 & 164.6 & 1127 & 60.9 \\
\hline
\end{tabular}

${ }^{a}$ SI conversion factor for ferritin values: To convert to pmol/L, multiply by 2.247 . 
TABLE 3. Unadjusted and Multivariate-Adjusted Means for Ferritin Levels in Relation to Dietary Variables, Stratified by Sex

\begin{tabular}{|c|c|c|c|c|c|c|c|c|}
\hline \multirow[b]{2}{*}{ Dietary consumption and level of ingestion } & \multicolumn{4}{|c|}{ Men } & \multicolumn{4}{|c|}{ Women } \\
\hline & No. & $\begin{array}{c}\text { Unadjusted } \\
\text { mean } \\
(\mu \mathrm{g} / \mathrm{L})^{\mathrm{a}}\end{array}$ & $\begin{array}{c}\text { Adjusted }^{\mathrm{b}} \\
\text { mean } \\
(\mu \mathrm{g} / \mathrm{L})^{\mathrm{a}}\end{array}$ & $\begin{array}{c}P \\
\text { value }^{\mathrm{c}}\end{array}$ & No. & $\begin{array}{c}\text { Unadjusted } \\
\text { mean } \\
(\mu \mathrm{g} / \mathrm{L})^{\mathrm{a}}\end{array}$ & $\begin{array}{c}\text { Adjusted }^{\mathrm{b}} \\
\text { mean } \\
(\mu \mathrm{g} / \mathrm{L})^{\mathrm{a}}\end{array}$ & $\begin{array}{c}P \\
\text { value }^{\mathrm{c}}\end{array}$ \\
\hline \multicolumn{9}{|l|}{$\begin{array}{l}\text { How many times per week do you eat oranges or } \\
\text { grapefruit or drink the juice of these citrus fruits? }\end{array}$} \\
\hline 0 & 214 & 173.0 & 168.5 & & 229 & 64.8 & 63.9 & \\
\hline $1-3$ & 376 & 160.0 & 158.4 & & 387 & 56.8 & 59.8 & \\
\hline $4-6$ & 223 & 176.0 & 173.8 & & 240 & 59.3 & 58.5 & \\
\hline$\geq 7$ & 292 & 156.2 & 162.9 & .54 & 271 & 65.6 & 62.5 & .65 \\
\hline \multicolumn{9}{|l|}{$\begin{array}{l}\text { How many pieces of other kinds of fresh fruit } \\
\text { do you eat each week? }\end{array}$} \\
\hline $0-3$ & 294 & 183.6 & 179.6 & & 193 & 56.9 & 63.2 & \\
\hline $4-6$ & 224 & 181.2 & 179.9 & & 191 & 64.0 & 63.4 & \\
\hline $7-13$ & 341 & 155.9 & 159.6 & & 413 & 59.0 & 59.2 & \\
\hline$\geq 14$ & 246 & 142.6 & 142.6 & .002 & 330 & 64.2 & 60.4 & .75 \\
\hline \multicolumn{9}{|l|}{$\begin{array}{l}\text { How many times per week do you eat potatoes } \\
\text { with your meal? }\end{array}$} \\
\hline $0-3$ & 243 & 151.5 & 149.2 & & 297 & 54.4 & 61.3 & \\
\hline $4-6$ & 622 & 169.2 & 169.4 & & 622 & 61.1 & 60.3 & \\
\hline$\geq 7$ & 240 & 166.5 & 168.5 & .10 & 208 & 71.2 & 62.5 & .87 \\
\hline \multicolumn{9}{|l|}{$\begin{array}{l}\text { How many times per week do you eat other } \\
\text { cooked vegetables with your meal? }\end{array}$} \\
\hline $0-3$ & 86 & 176.5 & 173.4 & & 94 & 48.7 & 58.8 & \\
\hline $4-6$ & 557 & 167.0 & 164.5 & & 529 & 56.3 & 57.0 & \\
\hline$\geq 7$ & 462 & 159.6 & 163.0 & .81 & 504 & 69.0 & 65.8 & .031 \\
\hline \multicolumn{9}{|l|}{ How many times per week do you eat salads? } \\
\hline $0-3$ & 651 & 164.3 & 162.9 & & 605 & 60.4 & 60.1 & \\
\hline $4-6$ & 308 & 165.9 & 164.8 & & 340 & 59.4 & 61.3 & \\
\hline$\geq 7$ & 144 & 161.6 & 170.6 & .82 & 182 & 66.1 & 63.3 & .76 \\
\hline \multicolumn{9}{|l|}{ Do you take vitamin $\mathrm{C}$ alone or in multivitamins? } \\
\hline No & 907 & 166.8 & 166.4 & & 817 & 60.5 & 60.0 & \\
\hline Yes & 198 & 154.7 & 156.5 & .33 & 310 & 62.2 & 63.4 & .35 \\
\hline \multicolumn{9}{|l|}{$\begin{array}{l}\text { How many times per week do you eat red meat? } \\
\text { (hot, cold, in sandwiches) }\end{array}$} \\
\hline $0-3$ & 266 & 141.2 & 144.9 & & 380 & 50.2 & 50.5 & \\
\hline $4-6$ & 466 & 165.2 & 163.4 & & 542 & 67.7 & 67.0 & \\
\hline$\geq 7$ & 373 & 182.8 & 181.8 & .002 & 205 & 66.0 & 67.0 & $<.001$ \\
\hline \multicolumn{9}{|l|}{ Do you eat liver or kidney each week? } \\
\hline No & 1074 & 163.3 & 163.5 & & 1095 & 60.3 & 60.5 & \\
\hline Yes & 31 & 215.5 & 208.1 & .09 & 32 & 88.4 & 78.2 & .10 \\
\hline \multicolumn{9}{|l|}{ How many eggs do you eat weekly? } \\
\hline $0-1$ & 307 & 156.2 & 156.4 & & 421 & 60.1 & 62.8 & \\
\hline $2-3$ & 441 & 165.6 & 165.3 & & 502 & 60.9 & 59.4 & \\
\hline$\geq 4$ & 357 & 170.7 & 171.0 & .35 & 204 & 62.8 & 61.1 & .62 \\
\hline \multicolumn{9}{|l|}{ How many cups daily? } \\
\hline \multicolumn{9}{|l|}{ Tea } \\
\hline 0 & 289 & 163.2 & 164.5 & & 256 & 50.9 & 58.1 & \\
\hline $1-3$ & 477 & 171.5 & 171.4 & & 497 & 63.1 & 64.3 & \\
\hline$\geq 4$ & 339 & 156.3 & 155.4 & .23 & 374 & 65.9 & 58.6 & .17 \\
\hline \multicolumn{9}{|l|}{ Coffee } \\
\hline 0 & 334 & 163.3 & 162.9 & & 368 & 58.6 & 58.7 & \\
\hline $1-3$ & 552 & 170.0 & 170.4 & & 575 & 63.4 & 62.1 & \\
\hline$\geq 4$ & 219 & 153.5 & 153.1 & .23 & 184 & 58.4 & 61.9 & .61 \\
\hline \multicolumn{9}{|l|}{ Alcohol consumption in $\mathrm{g} / \mathrm{wk}$} \\
\hline Nondrinker & 41 & 117.6 & 122.1 & & 95 & 64.1 & 53.5 & \\
\hline Ex-drinker & 73 & 134.0 & 133.3 & & 118 & 64.3 & 56.5 & \\
\hline$\leq 140$ & 535 & 153.0 & 153.3 & & 816 & 58.3 & 60.4 & \\
\hline $141-420$ & 373 & 184.8 & 185.5 & & 93 & 75.7 & 79.9 & \\
\hline$>420$ & 83 & 221.0 & 212.0 & $<.001$ & 5 & 168.1 & 133.7 & .003 \\
\hline
\end{tabular}

${ }^{a}$ SI conversion factor: To convert ferritin values to $\mathrm{pmol} / \mathrm{L}$, multiply by 2.247 .

${ }^{\mathrm{b}}$ Adjusted for body mass index, history of ulcer, doctor-diagnosed diabetes, anemia, blood donation, menopausal status, hysterectomy, and $H F E$ genotype.

${ }^{\mathrm{c}} P$ values apply to the overall test of no differences across the levels of the diet variable. 
consuming on average 2 or more pieces of fruit a day were slightly lower in the group consuming the most red meat (7 or more times per week) than in the group consuming the least red meat (0-3 times per week): $21 \%$ vs $29 \%$ for men and $23 \%$ vs $34 \%$ for women, respectively. However, there was no evidence that red meat and fruit interacted in their effects on serum ferritin levels (men $P=.41$; women $P=.12$ ). In other words, the magnitude of the effect of fruit intake on serum ferritin was the same regardless of the level of red meat consumption and vice versa.

We also examined whether the effect of fruit consumption on ferritin levels is confounded by meat intake. After adjustment for meat consumption, the effect of fruit consumption on ferritin remained significant in men $(P=.002)$ and continued to be nonsignificant in women $(P=.71)$. Therefore the strong effect of fruit consumption on ferritin levels in men is not explained by ingestion of red meat.

Egg yolk can inhibit iron uptake. ${ }^{23}$ Approximately a quarter of the group (32.9\% of men and $17.5 \%$ of women) ate 4 or more eggs a week; however, no significant effects or trends of any kind were seen in effects on iron status (all $P$ values $>$.1, data not shown).

\section{Tea and Coffee}

Consumption of polyphenol-containing beverages, including both tea and coffee, might inhibit iron absorption, as reviewed previously. ${ }^{16,23,24}$ Coffee also has ferritin-reducing antioxidant activity that might reflect the presence of chlorogenic acids ${ }^{25}$ and could lead indirectly to changes in iron status. However, we found no significant effects or trends of any kind in the effects of tea or coffee consumption on serum ferritin levels in either sex, irrespective of age adjustment or multivariate adjustment (all $P$ values >.1).

\section{ALCOHOL}

Consistent with our previously reported study in the Busselton population ${ }^{9,19}$ and other previous reports, ${ }^{26}$ current data showed significantly higher serum ferritin levels with higher alcohol consumption in both men and women, and this was independent of $H F E$ genotype. There were no significant interactions observed between fruit consumption and alcohol intake $(P>.1)$. The effect of fruit on ferritin levels was the same regardless of alcohol consumption for both men and women.

Interactions Between Dietary Factors and HFE Mutations Of the 12 dietary factors examined, the only one found to have a significant interaction with $H F E$ genotype on serum ferritin levels was alcohol consumption in women $(P=.04)$. As many interactions were tested, this result could be a false-positive finding and requires confirmation in other studies.

\section{DISCUSSION}

Our results confirm that greater fruit consumption can reduce body iron stores, gauged by serum ferritin levels, as found in a UK study of relatives of probands with $H F E$ C282Y mutations. ${ }^{11}$ Our community-based study extends this finding to show that effects of fruit consumption may be significant across all men and not restricted to $\mathrm{C} 282 \mathrm{Y}$ mutation carriers. The protective effect of fruit is therefore potentially relevant to other important iron-overload conditions that do not involve HFE mutations, including thalassemia and sickle cell anemia. Approximately half of $\beta$-thalassemia major patients die before age 35 years, predominantly from iron-induced heart failure. ${ }^{27}$ Dietary modification might assist in optimizing dose regimens for new iron chelators now coming on the market to allow safer, more effective management of iron load.

In contrast to the effect seen in men, intake of noncitrus fruit did not correlate with serum ferritin levels in women. Intake of citrus fruits or citrus fruit juices did not correlate with serum ferritin levels in either sex. No other dietary factor examined reduced serum ferritin levels. Consistent with previous studies, ${ }^{9,19}$ increases in serum ferritin levels independent of HFE mutations occurred with greater consumption of alcohol and red meat. However, the strong effects of fruit intake on serum ferritin levels in men were independent of consumption of either alcohol or red meat.

Various fruit components (eg, fructose, fructo-oligosaccharides, fiber, complex carbohydrates, polyphenols, citric and ascorbic acids) have been investigated for effects on iron measures, but studies have been small and results inconclusive. The most consistent findings are probably for iron-binding polyphenols and oxalates, which inhibit nonheme iron absorption and are present in many noncitrus fruits and beverages such as tea and coffee. ${ }^{28-33}$ However, as noted above, no effects were observed for tea and coffee in our study, suggesting other factors found specifically in fruit might also be involved.

Two laboratory-controlled studies of humans found people fed fructose had higher fecal excretion of iron and magnesium than those fed sucrose. ${ }^{34}$ This could have reflected diarrhea; however, one rodent study found dietary fructose lowers ferrous iron absorption by lowering iron concentrations in the liquid phase of the intestinal lumen, reducing absorption. ${ }^{35}$ Other researchers report no effects of fructose ${ }^{36}$ or complex carbohydrate and fruit and vegetable fiber ${ }^{37-40}$ or (alternatively) that fructose and fructooligosaccharides, especially if fermented, increase iron absorption in rodents or humans. ${ }^{41-44}$ Variability arises from numerous factors, including whether single meals or the whole diet are examined, whether iron consumption occurs 
with or between meals, meal composition, and assessment methods used to estimate intake.

Although a model has been proposed in which greater fruit intake is associated with increased iron uptake and higher body iron stores, ${ }^{13,14,16}$ other large studies have provided little support for this, ${ }^{45}$ and few studies have analyzed $H F E$ genotype, have distinguished citrus from noncitrus fruit consumption, or have examined large cohorts over the broader age ranges examined in our study and the Welsh study by McCune et al. ${ }^{11}$ Orange juice is arguably the most commonly consumed food in Western countries that has been associated with increased uptake of dietary nonheme iron, probably reflecting its high ascorbate and citrate content. ${ }^{14,16}$ Both the ascorbic acid and the citric acid content of a fruit correlate with its ability to increase iron uptake, ${ }^{15}$ as reviewed elsewhere, ${ }^{23}$ and both might reduce inhibition of nonheme-iron absorption by polyphenols. ${ }^{46}$ However, neither our study nor that of McCune et $\mathrm{al}^{11}$ found any consistent effects of self-reported dietary vitamin C supplementation on iron status.

Rodent studies suggest a complex interplay between dietary iron, body iron status, and genetic factors in controlling gastrointestinal iron uptake. ${ }^{47-49}$ Most studies suggest the body normally regulates iron absorption tightly despite fluctuations in availability. The influence of dietary factors on iron status is thought to be inherently limited in most physiologic circumstances; however, dietary factors might have greater influence in some pathologic conditions, including inadequate dietary iron intake or $\mathrm{HH}$, and in some middleaged or elderly people with high intakes of red meat or other dietary factors associated with iron loading..$^{12,21,22,29,50}$ Four of the largest population studies to date, including the current study, all suggest dietary factors can influence iron status (positively or negatively) in people genetically at risk as well as in other groups. ${ }^{7,8,11}$ A combined strategy of increasing fruit consumption in conjunction with limiting consumption of alcohol and red meat can increase benefits. Other dietary factors not examined here could also have effects. Conversely, it might also be relevant to investigate potential implications for groups at risk of iron deficiency.

McCune et $\mathrm{al}^{11}$ found blood donation was one of a group of variables of borderline significance $(.05<P<.1)$, so blood donation might protect against high serum ferritin levels in people at risk of $\mathrm{HH}$. Our finding regarding fruit, obtained after adjustment for "ever having donated blood," is not due solely to blood donation. However, the data do not allow us to examine the degree of protection among men who consume high levels of fruit and have frequently or recently donated blood. High fruit consumption might benefit men whose iron levels are not well controlled by blood donation or might reduce the frequency of phlebotomy required to manage iron levels.
Increased fruit consumption could have benefits beyond those of reducing iron levels. Fructose might protect cells against oxidative injury by chelating iron. ${ }^{51}$ Polyphenols might have antioxidant and anti-inflammatory properties. ${ }^{31,52,53}$ Lowering serum ferritin levels could have benefits beyond reducing hemochromatosis risk, because serum ferritin levels correlate with hepatic fat and insulin resistance..$^{54-56}$

Limitations of the study include the potential for inaccuracy in self-reported dietary values and the many possible confounders that can affect outcomes in epidemiological studies of this kind. We are unable to determine from the available data whether the protective effect seen in men but not women reflects sex differences in a dietary factor not examined in our study, inherent sex differences in iron handling, or some other sex difference. Well-powered studies in other large populations are needed to address all these issues.

\section{CONCLUSION}

Noncitrus fruits are environmental modifiers of iron status in men, independent of various other dietary constituents and of $H F E$ genotype. Besides potential health benefits in patients with $\mathrm{HH}$, this observation could have broader public health utility, particularly for countries in which ironoverload disorders occur frequently. Our findings have relevance for health campaigns directed at people at risk of iron overload. Their effectiveness could be increased by including promotion of healthy diet choices (high fruit consumption with reduced consumption of red meat and alcohol) in addition to highlighting the benefits of blood donation if appropriate to the clinical circumstances.

We thank the Busselton Population Medical Research Foundation and the community of Busselton, Western Australia.

\section{REFERENCES}

1. Siah CW, Ombiga J, Adams LA, Trinder D, Olynyk JK. Normal iron metabolism and the pathophysiology of iron overload disorders. Clin Biochem Rev. 2006;27(1):5-16.

2. Pietrangelo A. Hereditary hemochromatosis. Biochim Biophys Acta. 2006 Jul;1763(7):700-710. Epub 2006 May 27.

3. Whitlock EP, Garlitz BA, Harris EL, Beil TL, Smith PR. Screening for hereditary hemochromatosis: a systematic review for the U.S. Preventive Services Task Force. Ann Intern Med. 2006;145(3):209-223.

4. Beutler E. Hemochromatosis: genetics and pathophysiology. Annu Rev Med. 2006 Feb;57:331-347.

5. Feder JN, Gnirke A, Thomas W, et al. A novel MHC class I-like gene is mutated in patients with hereditary haemochromatosis. Nat Genet. 1996;13(4): 399-408.

6. Powell LW, Dixon JL, Ramm GA, et al. Screening for hemochromatosis in asymptomatic subjects with or without a family history. Arch Intern Med. 2006;166(3):294-301.

7. Van der A DL, Peeters PHM, Grobbee DE, Roest M, Voorbij HAM, Van der Schouw YT. HFE genotypes and dietary heme iron: no evidence of strong gene-nutrient interaction on serum ferritin concentrations in middle-aged women. Nutr Metab Cardiovasc Dis. 2006;16(1):60-68 
8. Greenwood DC, Cade JE, Moreton JA, et al. HFE genotype modifies the influence of heme iron intake on iron status. Epidemiology. 2005;16(6):802805.

9. Rossi E, Bulsara MK, Olynyk JK, Cullen DJ, Summerville L, Powell LW. Effect of hemochromatosis genotype and lifestyle factors on iron and red cell indices in a community population. Clin Chem. 2001;47(2):202-208.

10. Leggett BA, Brown NN, Bryant SJ, Duplock L, Powell LW, Halliday JW. Factors affecting the concentration of ferritin in serum in a healthy Australian population. Clin Chem. 1990;36(7):1350-1355.

11. McCune CA, Ravine $\mathrm{D}$, Carter $\mathrm{K}$, et al. Iron loading and morbidity among relatives of HFE C282Y homozygotes identified either by population genetic testing or presenting as patients. Gut. 2006 Apr;55(4):554-562. Epub 2005 Sep 20.

12. Cade JE, Moreton JA, O'Hara B, et al. Diet and genetic factors associated with iron status in middle-aged women. Am J Clin Nutr. 2005;82(4):813-820.

13. Fleming DJ, Jacques PF, Dallal GE, Tucker KL, Wilson PWF, Wood RJ. Dietary determinants of iron stores in a free-living elderly population: The Framingham Heart Study. Am J Clin Nutr. 1998;67(4):722-733.

14. Fleming DJ, Tucker KL, Jacques PF, Dallal GE, Wilson PW, Wood RJ. Dietary factors associated with the risk of high iron stores in the elderly Framingham Heart Study cohort. Am J Clin Nutr. 2002;76(6):1375-1384.

15. Ballot $\mathrm{D}$, Baynes RD, Bothwell $\mathrm{TH}$, et al. The effects of fruit juices and fruits on the absorption of iron from a rice meal. Br J Nutr. 1987;57(3):331-343.

16. Crawford RD. Proposed role for a combination of citric acid and ascorbic acid in the production of dietary iron overload: a fundamental cause of disease. Biochem Mol Med. 1995;54(1):1-11.

17. Olynyk JK, Cullen DJ, Aquilia S, Rossi E, Summerville L, Powell LW. A population-based study of the clinical expression of the hemochromatosis gene. N Engl J Med. 1999;341(10):718-724.

18. Cullen KJ. Mass health examinations in the Busselton population. Med J Aust. 1972;2(13):714-718.

19. Olynyk JK, Knuiman MW, Divitini ML, Bartholomew HC, Cullen DJ, Powell LW. Effects of HFE gene mutations and alcohol on iron status, liver biochemistry and morbidity. J Gasteroenterol Hepatol. 2005;20(9):1435-1441.

20. Mei Z, Cogswell ME, Parvanta I, et al. Hemoglobin and ferritin are currently the most efficient indicators of population response to iron interventions: an analysis of nine randomized controlled trials. J Nutr. 2005;135(8): 1974-1980.

21. Fleming DJ, Jacques PF, Tucker KL, et al. Iron status of the free-living, elderly Framingham Heart Study cohort: an iron-replete population with a high prevalence of elevated iron stores. Am J Clin Nutr. 2001;73(3):638-646.

22. Beard J. Dietary iron intakes and elevated iron stores in the elderly: is it time to abandon the set-point hypothesis of regulation of iron absorption [editorial]? Am J Clin Nutr. 2002;76(6):1189-1190.

23. Hallberg L, Hulthen L. Prediction of dietary iron absorption: an algorithm for calculating absorption and bioavailability of dietary iron [published corrections appear in Am J Clin Nutr. 2000;72(5):1242, 2001;74(2):274, and 2006;84(5):1253]. Am J Clin Nutr. 2000;71(5):1147-1160.

24. Nelson M, Poulter J. Impact of tea drinking on iron status in the UK: a review. J Hum Nutr Diet. 2004;17(1):43-54.

25. Moreira DP, Monteiro MC, Ribeiro-Alves M, Donangelo CM, Trugo LC. Contribution of chlorogenic acids to the iron-reducing activity of coffee beverages. J Agric Food Chem. 2005;53(5):1399-1402.

26. Ioannou GN, Dominitz JA, Weiss NS, Heagerty PJ, Kowdley KV. The effect of alcohol consumption on the prevalence of iron overload, iron deficiency, and iron deficiency anemia. Gastroenterology. 2004;126(5):1293-1301.

27. Anderson LJ, Wonke B, Prescott E, Holden S, Walker JM, Pennell DJ. Comparison of effects of oral deferiprone and subcutaneous desferrioxamine on myocardial iron concentrations and ventricular function in betathalassaemia. Lancet. 2002;360(9332):516-520.

28. Brat $\mathrm{P}$, George S, Bellamy A, et al. Daily polyphenol intake in France from fruit and vegetables. J Nutr. 2006;136(9):2368-2373.

29. Hallberg L. Advantages and disadvantages of an iron-rich diet. Eur J Clin Nutr. 2002;56(suppl 1):S12-S18.

30. Mennen LI, Walker R, Bennetau-Pelissero C, Scalbert A. Risks and safety of polyphenol consumption. Am J Clin Nutr. 2005;81(1)(suppl):326S329S.

31. Yoshino M, Murakami K. Interaction of iron with polyphenolic compounds: application to antioxidant characterization. Anal Biochem. 1998;257(1): 40-44

32. Hurrell RF, Reddy M, Cook JD. Inhibition of non-haem iron absorption in man by polyphenolic-containing beverages. Br J Nutr. 1999;81(4):289-295.
33. Jyothi Lakshmi A, Gupta S, Prakash J. Comparative analysis of influence of promoters and inhibitors on in vitro available iron using two methods. Int $J$ Food Sci Nutr. 2006;57(7-8):559-569.

34. Ivaturi R, Kies C. Mineral balances in humans as affected by fructose, high fructose corn syrup and sucrose. Plant Foods Hum Nutr. 1992;42(2):143-151.

35. Brouwer IA, Lemmens AG, Beynen AC. Dietary fructose v. glucose lowers ferrous-iron absorption in rats. Br J Nutr. 1993;70(1):171-178.

36. Bell RC, Sakanashi TM, Keen CL, Finegood DT. High fructose intake significantly reduces kidney copper concentrations in diabetic, islet transplanted rats. Biol Trace Elem Res. 1998;61(2):137-149.

37. Hallfrisch J, Powell A, Carafelli C, Reiser S, Prather ES. Mineral balances of men and women consuming high fiber diets with complex or simple carbohydrate. J Nutr. 1987;117(1):48-55.

38. Kelsay JL, Frazier CW, Prather ES, Canary JJ, Clark WM, Powell AS Impact of variation in carbohydrate intake on mineral utilization by vegetarians. Am J Clin Nutr. 1988;48(3)(suppl):875-879.

39. Kelsay JL, Prather ES, Clark WM, Canary JJ. Mineral balances of men fed a diet containing fiber in fruits and vegetables and oxalic acid in spinach for six weeks. J Nutr. 1988;118(10):1197-1204.

40. Mason PM, Judd PA, Fairweather-Tait SJ, Eagles J, Minski MJ. The effect of moderately increased intakes of complex carbohydrates (cereals, vegetables and fruits) for 12 weeks on iron and zinc metabolism. Br J Nutr. 1990; d63(3):597-611.

41. Ohta A, Ohtsuki M, Baba S, Takizawa T, Adachi T, Kimura S. Effects of fructooligosaccharides on the absorption of iron, calcium and magnesium in iron-deficient anemic rats. J Nutr Sci Vitaminol (Tokyo). 1995;41(3):281-291.

42. Ohta A, Sakai K, Takasaki M, Uehara M, Tokunaga T, Adachi T. Dietary heme iron does not prevent postgastrectomy anemia but fructooligosaccharides improve bioavailability of heme iron in rats. Int J Vitam Nutr Res. 1999;69(5): 348-355.

43. Conrad ME, Umbreit JN, Moore EG. A role for mucin in the absorption of inorganic iron and other metal cations: a study in rats. Gastroenterology. 1991;100(1):129-136.

44. Holbrook JT, Smith JC Jr, Reiser S. Dietary fructose or starch: effects on copper, zinc, iron, manganese, copper, and magnesium balances in humans. Am J Clin Nutr. 1989;49(6):1290-1294.

45. Doyle W, Crawley H, Robert H, Bates CJ. Iron deficiency in older people: interactions between food and nutrient intakes with biochemical measures of iron; further analysis of the National Diet and Nutrition Survey of people aged 65 years and over. Eur J Clin Nutr. 1999;53(7):552-559.

46. Siegenberg D, Baynes RD, Bothwell TH, et al. Ascorbic acid prevents the dose-dependent inhibitory effects of polyphenols and phytates on nonheme-iron absorption. Am J Clin Nutr. 1991;53(2):537-541.

47. Ludwiczek S, Theurl I, Artner-Dworzak E, Chorney M, Weiss G. Duodenal HFE expression and hepcidin levels determine body iron homeostasis: modulation by genetic diversity and dietary iron availability. $\mathrm{J} \mathrm{Mol} \mathrm{Med}$. 2004 Jun;82(6):373-382. Epub 2004 May 13.

48. Chen H, Su T, Attieh ZK, et al. Systemic regulation of hephaestin and Ireg1 revealed in studies of genetic and nutritional iron deficiency. Blood. 2003 Sep 1;102(5):1893-1899. Epub 2003 May 1.

49. Morgan EH, Oates PS. Mechanisms and regulation of intestinal iron absorption. Blood Cells Mol Dis. 2002;29(3):384-399.

50. Garry PJ, Montoya GD, Baumgartner RN, Liang HC, Williams TM, Brodie SG. Impact of HLA-H mutations on iron stores in healthy elderly men and women. Blood Cells Mol Dis. 1997;23(2):277-287.

51. Valeri F, Boess F, Wolf A, Goldlin C, Boelsterli UA. Fructose and tagatose protect against oxidative cell injury by iron chelation. Free Radic Biol Med. 1997;22(1-2):257-268

52. Rahman I, Biswas SK, Kirkham PA. Regulation of inflammation and redox signaling by dietary polyphenols. Biochem Pharmacol. 2006 Nov 30; 72(11):1439-1452. Epub 2006 Aug 21.

53. Dew TP, Day AJ, Morgan MR. Xanthine oxidase activity in vitro: effects of food extracts and components. J Agric Food Chem. 2005;53(16):6510-6515.

54. Iwasaki T, Nakajima A, Yoneda M, et al. Serum ferritin is associated with visceral fat area and subcutaneous fat area. Diabetes Care. 2005;28(10):24862491

55. Chen J, Wildman RP, Hamm LL, et al. Association between inflammation and insulin resistance in U.S. nondiabetic adults: results from the Third National Health and Nutrition Examination Survey. Diabetes Care. 2004;27(12):29602965

56. Jehn M, Clark JM, Guallar E. Serum ferritin and risk of the metabolic syndrome in U.S. adults. Diabetes Care. 2004;27(10):2422-2428. 